\title{
Change in nutrient composition of biochar from rice husk and sugarcane bagasse at varying pyrolytic temperatures
}

\author{
Ifeoma Monica Nwajiaku ${ }^{1,2}$ - John Seye Olanrewaju $u^{1,3} \cdot$ Kuniaki Sato $^{1} \cdot$ Takeo Tokunari $^{4} \cdot$ Shigeru Kitano $^{4}$. \\ Tsugiyuki Masunaga ${ }^{1}$
}

Received: 12 December 2017 / Accepted: 11 August 2018 / Published online: 17 August 2018

(c) The Author(s) 2018

\begin{abstract}
Purpose Waste management is one of the significant challenges facing Nigeria's agricultural sector. To manage this problem, the conversion of agricultural wastes to biochar is a practical solution.

Methods In this work, the chemical composition of biochar from rice husk and sugarcane bagasse, two predominant agricultural wastes, commonly generated in Nigeria was studied. These wastes were pyrolyzed at $300-700$ and $350-700{ }^{\circ} \mathrm{C}$ for rice husk biochar (RHB) and sugarcane bagasse biochar (SBB), respectively.

Results It was found that biochar yield and total nitrogen decreased with increasing pyrolysis temperature while ash content, $\mathrm{pH}, \mathrm{EC}$, total carbon, extractable $\mathrm{Ca}, \mathrm{Mg}, \mathrm{Na}$, available phosphorus and silica were increased. In RHB, extractable $\mathrm{K}$ increased with increasing pyrolysis temperature, while in SBB it decreased with its maximum observed in RHB.

Conclusions Rice husk pyrolyzed at high temperature may produce nutrient-rich biochar with high nutrient contents and these could ameliorate acidic soils. Finally, SBB could give high available silicon with acid pre-treatment.
\end{abstract}

Keywords Rice husk $\cdot$ Sugarcane bagasse $\cdot$ Pyrolysis temperature $\cdot$ Nutrient content $\cdot$ Biochar

\section{Introduction}

In Nigeria, human population has been increasing rapidly. In 2016, Nigeria's population was estimated to about 188.9 million (UNDESA/PD 2017). To sustain the food requirement for the teaming population, there is need for increase in food production. Food production increase means an increase in agricultural system and with increase in agricultural system a significant amount of waste will be generated (Walsh et al. 2000). It has been reported that about 140 billion metric tonnes of waste biomass are solely generated globally from agricultural activities every year (UNEP 2009). Rice husk is

Tsugiyuki Masunaga

masunaga@life.shimane-u.ac.jp

1 Faculty of Life and Environmental Science, Shimane University, 1060 Nishikawatsu, Matsue, Shimane 690-8504, Japan

2 Imo State University, Owerri, Nigeria

3 New Sawah Project, National Centre for Agricultural Mechanization (NCAM), Ilorin, Nigeria

4 Meiwa Kogyo Co. Ltd, Kanazawa, Japan one of the most widely available agricultural wastes in many rice producing countries of the world and produces about $20-23 \%$ by weight of the entire paddy processed (Kumar et al. 2013; Giddel and Jivan 2007). In Nigeria, for example, an estimated amount of about 1,032,993.6 metric tonnes of rice husk are generated annually (NAERLS/PCU 2004).

Sugarcane bagasse, a fibrous residual material derived from sugarcane after extracting its juice, is also a common agricultural waste. Traditionally, in the sugar mill bagasse is used as fuel in steam production for the milling process and electricity generation. In Nigeria, from the recent record, an estimate of 1.06 million tonnes of sugarcane were produced out of which about $30 \%$ of bagasse residue was generated by sugarcane processed in the mill (FOASTAT 2014). Not all bagasse produced are used; a substantial amount is left unused for the remainder of the year. The conversion of these wastes into biochar can result in advantages, such as sustainable waste recycling and carbon sequestration.

Biochar, a carbon rich and porous substance produced by thermal decomposition of biomass under oxygen-limited and relatively low temperature $\left(<700^{\circ} \mathrm{C}\right)$ conditions, is receiving great research attention (Lehmann and Joseph 2009). This is due to its potential importance in agronomy 
and environment. Application of biochar on soil has been shown to have a clear effect on improving soil fertility, crop production and on decontamination of pollutants such as pesticides, heavy metals and hydrocarbon (Beesley et al. 2011; Cabrera et al. 2011). According to Lehmann et al. (2011), physico-chemical properties of biochar can cause changes in the soil nutrient and $\mathrm{C}$ availability and also provide physical protection to microorganisms against predators and desiccation. The type of biomass from which biochar is produced is another important factor. This is because its properties are affected by the nature of the original material. For instance, biochar from manure source possess higher soil cation exchange capacity than that from wood source (Singh et al. 2010). Again, treating soil with woodchip biochar results in higher saturated hydraulic conductivities than with manure-based biochar (Lei and Zhang 2013).

There has been a growing interest in the creation of recycling society in which wastes are steadily reduced. The technology that is used to produce biochar from waste started in antiquity, but recently there is a growing interest on pyrolysis. This is because pyrolysis is seen as an effective process for converting biomass into resources. The process of pyrolysis concentrates plant nutrients such as phosphorus, potassium, calcium, magnesium and sodium as heating temperature increases (Camps-Arbestain et al. 2015). Consequently, research has proven that even with the concentration of nutrients, percentage retention of alkaline earth metals is higher as opposed to the alkali metals. However, the release and retention of divalent alkaline earth metals are of great importance when biochar acts as a soil amendment (Okuno et al. 2005). Nitrogen is the most important nutrient for plant, but some parts (forms) of $\mathrm{N}$ are lost by pyrolysis. $\mathrm{N}$ containing organic materials when exposed to high temperature lead to the enrichment of the heterocyclic form of $\mathrm{N}$ such as pyrrole-type $\mathrm{N}$ with a decrease in amide N (Knicker and Hatcher 1997). According to Almendros et al. (2003), the microbial decomposition of the enriched $\mathrm{N}$ compounds is relatively recalcitrant which limit the conversion of these compounds to plant available form of $\mathrm{N}$. Hongguang et al. (2017) also explained the importance of these enriched heterocyclic $\mathrm{N}$ compounds when he observed significant decrease on nitrogen loss from $109.6 \mathrm{mg} \mathrm{kg}^{-1}$ $(0.01 \%)$ to $53.3 \mathrm{mg} \mathrm{kg}^{-1}(0.005 \%)$ in relation to increase in temperature on soils amended with biochar pyrolyzed at 250 , 350,450 and $550{ }^{\circ} \mathrm{C}$.

However, not much research attention has been given on the extent to which different sources of biomass and pyrolysis temperature could increase the efficiency of applied biochar in soil sustainability and crop productivity. The use of biochar to ameliorate the soil physical properties for instance porosity and chemical properties for instance chelating nutrients is a function of biomass and pyrolysis condition as well as quantity (Kammann et al. 2011; Van Zwieten et al.
2009; Kudeyarova 2007). Therefore, there is need to study the changes in chemical composition of biochar in relation to pyrolysis temperature. In this study, we tend to control the chemical composition of biochar by investigating different pyrolysis temperatures and agricultural wastes used as biomass. To achieve this aim, the chemical properties of biochar of rice husk at different temperature $\left(300-700{ }^{\circ} \mathrm{C}\right)$ using continuous and plant-size carbonizer and sugarcane bagasse at different temperature $\left(350-700{ }^{\circ} \mathrm{C}\right)$ using batch type carbonizer were evaluated.

\section{Materials and methods}

\section{Biochar production}

The biochar used in this work was obtained from the two agricultural waste residues: rice husk (Oryza sativa L.) and sugarcane bagasse (Saccharum officinarum L.). All the materials were first air dried and the sugarcane bagasse was cut into smaller pieces (less than $4-5 \mathrm{~cm}$ ). Then, $10 \mathrm{~kg}$ of samples was inserted into a pilot batch type carbonizer (model ECO500, Meiwa Co. Ltd. Kanazawa) and pyrolyzed for $10 \mathrm{~min}$ after the inside chamber reached the target temperature.

\section{Biochar chemical composition characterization}

Prior to pyrolysis, the original biomass was analyzed for its chemical composition (Table 1). All samples were ground to less than $0.5 \mathrm{~mm}$ in diameter using manual agate

Table 1 Selected chemical properties of the original biomass prior to pyrolysis

\begin{tabular}{lcc}
\hline Analyzed parameters & Biomass \\
\cline { 2 - 3 } & Rice husk & $\begin{array}{c}\text { Sugarcane } \\
\text { bagasse }\end{array}$ \\
\hline $\mathrm{pH}$ & 6.5 & 5.1 \\
Electrical conductivity $\left(\mathrm{dS} \mathrm{m}^{-1}\right)$ & 0.33 & 0.32 \\
Ash content $(\%)$ & 11.5 & 4.0 \\
Available phosphorus $\left(\mathrm{P}_{2} \mathrm{O}_{5} \mathrm{mg} \mathrm{kg}^{-1}\right)$ & 605 & 1167 \\
Available silica $\left(\mathrm{SiO}_{2} \mathrm{mg} \mathrm{kg}^{-1}\right)$ & & \\
$0.1 \mathrm{M}$ citric acid & 295 & 398 \\
$0.5 \mathrm{M} \mathrm{HCl}$ & 109 & 145 \\
$0.1 \mathrm{M} \mathrm{CaCl}$ & 1004 & 753 \\
Total carbon $\left(\mathrm{g} \mathrm{kg}^{-1}\right)$ & 410.9 & 460.5 \\
Total nitrogen $\left(\mathrm{g} \mathrm{kg}^{-1}\right)$ & 2.7 & 2.7 \\
Total calcium $\left(\mathrm{mg} \mathrm{kg}^{-1}\right)$ & 509 & 1300 \\
Total magnesium $\left(\mathrm{mg} \mathrm{kg}^{-1}\right)$ & 222 & 518 \\
Total potassium $\left(\mathrm{mg} \mathrm{kg}^{-1}\right)$ & 2397 & 1939 \\
Total sodium $\left(\mathrm{mg} \mathrm{kg}^{-1}\right)$ & 636 & 512 \\
\hline
\end{tabular}


mortar and pestle after the pyrolysis process. The biochar yield was calculated as the proportion of the weight of product to the original material. Ash content determination was conducted according to the American Society for Testing and Materials D1752-84. The ash content was thus determined by measuring the weight loss that follows the combustion of about $1 \mathrm{~g}$ of biochar in a crucible at $750{ }^{\circ} \mathrm{C}$ after $3 \mathrm{~h}$. The $\mathrm{pH}$ and $\mathrm{EC}$ of biochar were measured in 1:20 w/v biochar-water extracts using $\mathrm{pH}$ and EC meters (Models D-15 and D-24 Horiba, Kyoto Japan, respectively) (modification in ratio from Ahmedna et al. 1997). Total carbon and nitrogen were determined by dry combustion method using automatic high sensitive NC analyzer (Model Sumigraph NC-22 Analyzer, Tokyo Japan). Total base cations: $\mathrm{Ca}, \mathrm{K}, \mathrm{Mg}$ and $\mathrm{Na}$ were determined after digestion of $0.05 \mathrm{~g}$ of biochar with $\mathrm{HNO}_{3}$ at $160{ }^{\circ} \mathrm{C}$ for $5 \mathrm{~h}$ using Teflon vessel and measured by Inductively Coupled Plasma Spectroscopy (Model ICPE-9000, Shimadzu Kyoto Japan). Available $\mathrm{P}$ was extracted by $\mathrm{NaHCO}_{3}$ and was determined by molybdenum blue method according to Olsen and Sommers (1982).

Extractable $\mathrm{Ca}, \mathrm{K}, \mathrm{Mg}$ and $\mathrm{Na}$, which consist of water soluble and ionically exchangeable fractions, were extracted by shaking for $1 \mathrm{~h} 0.2 \mathrm{~g}$ of biochar in $20 \mathrm{ml}$ of neutral $\mathrm{CH}_{3} \mathrm{COONH}_{4}$ and quantified on Inductively Coupled Plasma Spectroscopy (Model ICPE-9000, Shimadzu Kyoto Japan). Available silica from the biochar was extracted using $0.01 \mathrm{M} \mathrm{CaCl}_{2}$ (1:30 ratio, continuous shaking for $16 \mathrm{~h}$, filter) (modification in ratio from Haysom and Chapman 1975), $0.5 \mathrm{M} \mathrm{HCl}$ (1:50 ratio, shake for $1 \mathrm{~h}$, filter) (modification in ratio from Savant et al. 1999) and $0.1 \mathrm{M}$ Citric acid (1:50 ratio, shake for $2 \mathrm{~h}$, allow to stay overnight then shake for $1 \mathrm{~h}$, filter) (Acquaye and Tinsley 1964). Silicon concentrations from the supernatant were determined by molybdenum blue method and measured with spectrophotometer (Model UV 1800, Shimadzu Kyoto Japan) at a wavelength of $810 \mathrm{~nm}$.

\section{Statistical analysis}

The data were subjected to analysis of variance (ANOVA) using IBM package SPSS 20, while significant differences among the means were tested using Duncan's multiple range test $(P<0.05)$. The available $P$ graphs were plotted using Microsoft excel 2007.

\section{Results and discussion}

\section{Yield, chemical and elemental properties}

Table 2 summarizes the chemical and elemental properties of RHB and SBB. As pyrolysis temperature increases, the yield of biochar from both rice husk and sugarcane bagasse decreased from 55 to $35 \%$ and from 27 to $22 \%$, respectively. This was as a result of further disintegration of pyrolytic volatiles into low molecular weight organics and gases as heat passes through the biomass (Thangalazhy-Gopakumar et al. 2010). The relative ash content derived from different temperature ranges in the two biomass increases significantly $(P<0.05)$ as the pyrolysis temperature increased from 21.8 to $35.6 \%$ and 11.0 to $12.8 \%$ respectively. The ash content was higher in RHB. This was as a result of rich silica content found in rice plants, which relates strongly with the ash content in the biochar (Mukome et al. 2013). The increase could also be attributed to the progressive concentration of minerals and destructive volatilization of lingo-cellulosic matters as heat passes through the biomass (Tsai et al. 2012; Cao and Harris 2010).

The $\mathrm{pH}$ values of RHB and SBB ranged from 6.8 to 10.7 and 7.8 to 9.7 , respectively (Table 2 ). The $\mathrm{pH}$ of the two
Table 2 The chemical and elemental properties of the biomass at different pyrolysis temperature

\begin{tabular}{clllllll}
\hline Biomass & $\begin{array}{l}\text { Temperature } \\
\left({ }^{\circ} \mathrm{C}\right)\end{array}$ & $\begin{array}{l}\text { Biochar yield } \\
(\%)\end{array}$ & Ash content & $\begin{array}{l}\mathrm{pH} \\
\left(\mathrm{H}_{2} \mathrm{O}\right)\end{array}$ & $\begin{array}{l}\mathrm{EC} \\
\left.(\mathrm{dS} \mathrm{m})^{-1}\right)\end{array}$ & $\begin{array}{l}\text { Total C } \\
\left(\mathrm{g} \mathrm{kg}^{-1}\right)\end{array}$ \\
\hline Rice husk & 300 & 55 & $21.8 \pm 0.2 \mathrm{e}$ & $6.8 \pm 0.4 \mathrm{c}$ & $0.09 \pm 0 \mathrm{e}$ & 512.9 & 4.5 \\
& 400 & 44 & $27.5 \pm 0.3 \mathrm{~d}$ & $8.6 \pm 0.2 \mathrm{~b}$ & $0.13 \pm 0 \mathrm{~d}$ & 541.1 & 4.9 \\
& 500 & 36 & $32.8 \pm 0.2 \mathrm{c}$ & $10.4 \pm 0.4 \mathrm{a}$ & $0.23 \pm 0 \mathrm{c}$ & 546.7 & 4.7 \\
& 600 & 35 & $33.9 \pm 0 \mathrm{~b}$ & $10.6 \pm 0.1 \mathrm{a}$ & $0.31 \pm 0 \mathrm{~b}$ & 560.6 & 4.3 \\
& 700 & 35 & $35.6 \pm 0 \mathrm{a}$ & $10.7 \pm 0.1 \mathrm{a}$ & $0.40 . \pm 0 \mathrm{a}$ & 545.0 & 3.6 \\
Sugarcane & 350 & 27 & $11.0 \pm 0.6 \mathrm{c}$ & $7.8 \pm 0.6 \mathrm{bc}$ & $0.11 \pm 0 \mathrm{e}$ & 693.4 & 6.0 \\
bagasse & 400 & 24 & $11.0 \pm 0.4 \mathrm{bc}$ & $8.3 \pm 0.1 \mathrm{~b}$ & $0.12 \pm 0 \mathrm{~d}$ & 707.3 & 5.7 \\
& 500 & 24 & $11.5 \pm 0.5 \mathrm{bc}$ & $9.2 \pm 0.7 \mathrm{a}$ & $0.16 \pm 0 \mathrm{c}$ & 729.5 & 5.3 \\
& 600 & 22 & $12.4 \pm 0.1 \mathrm{ab}$ & $9.6 \pm 0.2 \mathrm{a}$ & $0.17 \pm 0 \mathrm{~b}$ & 702.2 & 4.7 \\
& 700 & 22 & $12.8 \pm 0.2 \mathrm{a}$ & $9.7 \pm 0 \mathrm{a}$ & $0.21 \pm 0 \mathrm{a}$ & 696.3 & 3.8 \\
\hline
\end{tabular}

Values followed by the same letter within RHB or SBB columns were not significantly different at $P<0.05$ according to Duncan's Multiple Range Test. Values represent mean \pm standard deviation of $(n=3)$ 
biochars increased significantly $(P<0.05)$ with increasing pyrolysis temperature and the maximum (10.7) was observed in RHB at $700{ }^{\circ} \mathrm{C}$. This could be attributed to higher ash content at higher temperature and also due to the hydrolysis of salts of $\mathrm{Ca}, \mathrm{K}$ and $\mathrm{Mg}$ as the pyrolysis temperature increases (Gaskin et al. 2008). The electrical conductivity (EC) which estimates the amount of total dissolved salts or the total amount of dissolved ions in the biochar varied from 0.09 to 0.40 and 0.11 to $0.21 \mathrm{dS} \mathrm{m}^{-1}$ in RHB and SBB, respectively (Table 2). The EC of the RHB and SBB increased significantly $(P<0.05)$ with increasing pyrolysis temperature and the highest EC $\left(0.40 \mathrm{dS} \mathrm{m}^{-1}\right)$ was observed in RHB at $700{ }^{\circ} \mathrm{C}$. The increase was likely due to the loss of volatile materials as temperature increases while promoting the relative concentrations of salts in the ash fraction (Gai et al. 2014; Ding et al. 2010).

The elemental composition of the RHB and SBB is also presented in Table 2. The carbon content ranged from 512.9 to $560.6 \mathrm{~g} \mathrm{~kg}^{-1}$ and from 693.4 to $729.5 \mathrm{~g} \mathrm{~kg}^{-1}$ in RHB and SBB, respectively. The maximum $\left(729.5 \mathrm{~g} \mathrm{~kg}^{-1}\right)$ was observed in SBB at $500{ }^{\circ} \mathrm{C}$. The increased biochars' carbon content with increasing pyrolysis temperature indicates that pyrolysis temperature promotes carbonization (Chun et al. 2004; Chen et al. 2012). This promotion was due to high degree of polymerization leading to more condensed carbon structure in the biochar (Lehmann and Joseph 2009). The increase in carbon content could also be associated with $\mathrm{H}$ and $\mathrm{O}$ loss from biochar as the pyrolysis temperature increases (Antal and Gronli Antal and Grønli 2003). Total nitrogen content was found to decrease with increased pyrolysis temperature from 4.9 to $3.6 \mathrm{~g} \mathrm{~kg}^{-1}$ and from 6.0 to $3.8 \mathrm{~g} \mathrm{~kg}^{-1}$ in RHB and SBB, respectively (Table 2). This is because when plant biomass is subjected to pyrolysis, their $\mathrm{N}$ containing structures, i.e., amino sugars, amino acids and amines, which are part of nitrogen transformed into heterocyclic $\mathrm{N}$ aromatic structures (Cao and Harris 2010; Koutcheiko et al. 2006). This implies that nitrogen will not be available to plants on the immediate but will be released with passage of time.

\section{Base nutrient composition}

Though there was an increase in the total concentration of base elements, there was no specific trend with increase in pyrolysis temperature (Table 3 ). They ranged from K (3105 to 4211 and 3753 to $4711 \mathrm{mg} \mathrm{kg}^{-1}$ ), Ca (1012 to 1619 and 1922 to $3844 \mathrm{mg} \mathrm{kg}^{-1}$ ), $\mathrm{Mg}$ (522 to 864 and 905 to $1711 \mathrm{mg} \mathrm{kg}^{-1}$ ) and $\mathrm{Na}$ (509 to 1629 and 1203 to $2660 \mathrm{mg} \mathrm{kg}^{-1}$ ) in RHB and SBB, respectively. The overall maximum $\mathrm{K}\left(4711 \mathrm{mg} \mathrm{kg}^{-1}\right.$ at $\left.350^{\circ} \mathrm{C}\right)$, Ca (3844 $\mathrm{mg} \mathrm{kg}^{-1}$ at $\left.400{ }^{\circ} \mathrm{C}\right), \mathrm{Mg}\left(1711 \mathrm{mg} \mathrm{kg}^{-1}\right.$ at $\left.350{ }^{\circ} \mathrm{C}\right)$ and $\mathrm{Na}\left(2660 \mathrm{mg} \mathrm{kg}^{-1}\right.$ at $\left.350{ }^{\circ} \mathrm{C}\right)$ were all observed in SBB. The increase found in the total base elements after pyrolysis of the original biomass is an indication that the relevant chemical components were concentrated in biochar as heat passed through the crop residues (Yuan et al. 2011). The loss of volatile compounds of the original materials after thermal degradation yielded the remaining nutrient content in the biochars (Amonette and Joseph 2009; Chan and Xu 2009).

Pyrolysis significantly altered the extractable nutrient elements in both RHB and SBB at $P<0.05$. Although, the extractable $\mathrm{Na}$ in $\mathrm{SBB}$ showed no significant difference, a change in its composition was observed with increasing pyrolysis temperature (Table 3 ). The extractable $\mathrm{K}$ and $\mathrm{Mg}$ of RHB increased with increasing pyrolysis temperature while extractable $\mathrm{Ca}$ and $\mathrm{Na}$ showed no specific trend. They ranged from $\mathrm{K}$ ( 165 to $684 \mathrm{mg} \mathrm{kg}^{-1}$ ), $\mathrm{Ca}(67$ to $103 \mathrm{mg} \mathrm{kg}^{-1}$ ), $\mathrm{Mg}$ (16 to $29 \mathrm{mg} \mathrm{kg}^{-1}$ ) and $\mathrm{Na}$ (21 to $38 \mathrm{mg} \mathrm{kg}^{-1}$ ). In SBB, the extractable $\mathrm{K}$ (Table 3) decreased significantly with increasing pyrolysis temperature from 396
Table 3 The base nutrient composition of the biomass at different pyrolysis temperature

\begin{tabular}{|c|c|c|c|c|c|c|c|c|c|}
\hline \multirow[t]{3}{*}{ Biomass } & \multirow{3}{*}{$\begin{array}{l}\text { Tempera- } \\
\text { ture }\left({ }^{\circ} \mathrm{C}\right)\end{array}$} & \multicolumn{4}{|c|}{$\mathrm{CH}_{3} \mathrm{COONH}_{4}$ extractable elements } & \multicolumn{4}{|c|}{ Total elements } \\
\hline & & $\mathrm{K}$ & $\mathrm{Ca}$ & $\mathrm{Mg}$ & $\mathrm{Na}$ & $\mathrm{K}$ & $\mathrm{Ca}$ & $\mathrm{Mg}$ & $\mathrm{Na}$ \\
\hline & & $\mathrm{mg} \mathrm{kg}^{-1}$ & & & & & & & \\
\hline \multirow[t]{5}{*}{ Rice husk } & 300 & $165 \pm 2 \mathrm{e}$ & $67 \pm 7 d$ & $16 \pm 4 c$ & $21 \pm 1 \mathrm{c}$ & 3357 & 1411 & 716 & 1596 \\
\hline & 400 & $380 \pm 4 d$ & $103 \pm 6 a$ & $19 \pm 3 b c$ & $32 \pm 8 \mathrm{a}$ & 4211 & 1619 & 864 & 1629 \\
\hline & 500 & $537 \pm 3 c$ & $90 \pm 7 b c$ & $21 \pm 1 b c$ & $26 \pm 0 b c$ & 3628 & 1240 & 631 & 700 \\
\hline & 600 & $608 \pm 7 b$ & $84 \pm 4 c$ & $23 \pm 1 b$ & $29 \pm 5 \mathrm{ab}$ & 3122 & 1012 & 522 & 603 \\
\hline & 700 & $684 \pm 6 a$ & $101 \pm 1 \mathrm{ab}$ & $29 \pm 0 \mathrm{a}$ & $38 \pm 1 \mathrm{a}$ & 3105 & 1027 & 585 & 509 \\
\hline \multirow[t]{5}{*}{ Sugarcane bagasse } & 350 & $396 \pm 3 a$ & $170 \pm 2 b$ & $18 \pm 2 a$ & $26 \pm 4 a$ & 4711 & 3721 & 1711 & 2660 \\
\hline & 400 & $378 \pm 4 b$ & $167 \pm 2 b$ & $16 \pm 2 a$ & $25 \pm 5 a$ & 4417 & 3844 & 1656 & 2028 \\
\hline & 500 & $332 \pm 6 c$ & $153 \pm 5 c$ & $13 \pm 0 b$ & $23 \pm 2 a$ & 3753 & 1922 & 905 & 1368 \\
\hline & 600 & $304 \pm 9 d$ & $137 \pm 4 d$ & $13 \pm 0 b$ & $22 \pm 2 a$ & 4287 & 2053 & 986 & 1590 \\
\hline & 700 & $251 \pm 1 \mathrm{e}$ & $180 \pm 7 a$ & $16 \pm 1 \mathrm{a}$ & $24 \pm 3 a$ & 3951 & 2253 & 949 & 1203 \\
\hline
\end{tabular}

Values followed by the same letter within RHB or SBB columns were not significantly different at $P<0.05$ according to Duncan's Multiple Range Test. Values represent mean \pm standard deviation of $(n=3)$ 
to $251 \mathrm{mg} \mathrm{kg}^{-1}$ while extractable $\mathrm{Mg}$, Ca and $\mathrm{Na}$ decreased from $350{ }^{\circ} \mathrm{C}\left(18,170\right.$ and $\left.26 \mathrm{mg} \mathrm{kg}^{-1}\right)$ to $600{ }^{\circ} \mathrm{C}(13,137$ and $\left.22 \mathrm{mg} \mathrm{kg}^{-1}\right)$ and afterwards an increase was observed at $700{ }^{\circ} \mathrm{C}\left(16,180\right.$ and $\left.24 \mathrm{mg} \mathrm{kg}^{-1}\right)$. The overall maximum $\mathrm{Ca}\left(180 \mathrm{mg} \mathrm{kg}^{-1}\right)$ was observed in SBB at $700{ }^{\circ} \mathrm{C}$ while maximum $\mathrm{K}\left(684 \mathrm{mg} \mathrm{kg}^{-1}\right), \mathrm{Mg}\left(29.0 \mathrm{mg} \mathrm{kg}^{-1}\right)$ and $\mathrm{Na}$ $\left(38 \mathrm{mg} \mathrm{kg}^{-1}\right.$ ) were observed in RHB at $700{ }^{\circ} \mathrm{C}$. Extractable $\mathrm{K}$ data obtained indicate that for $\mathrm{K}$ release, higher temperature is required. This is because as heat passes through the biomass during combustion, they tend to induce higher effective reaction temperature. This leads to an increase in vapor pressure and the convective flux of $\mathrm{KCl}$ (Johansen et al. 2011). At higher temperature in RHB, sublimated $\mathrm{KCl}$ was not volatilized but rather combines with silicate to form potassium silicate (Muthadhi et al. 2007). In SBB, a decrease in extractable $\mathrm{K}$ was observed with increasing pyrolysis temperature, which could be as a result of higher diffusional resistance during devolatilization due to still intact organic matrix as heat passes through the biomass. (Van Lith et al. 2008).

\section{Available phosphorous}

In RHB, phosphorous availability significantly increased ( 225 to $1842 \mathrm{mg} \mathrm{kg}^{-1}$ ) with increasing pyrolysis temperature at $P<0.05$ (Fig. 1). Though SBB is statistically significant at $P<0.05$, it was found to have irregular trend with increasing pyrolysis temperature (Fig. 2). In biochar, its $\mathrm{P}$ content is a function of the type of biomass and pyrolysis condition (Downie et al. 2009). Generally, charring enhances $P$ availability from plant tissue. This is because with combustion, there is disproportionate volatilization of carbon which leads to cleavage of organic phosphorus bonds and hence yields biochar with high soluble phosphorus salts (Knoepp et al. 2005). This was in line with the continuous increase of available P observed in RHB with increasing pyrolysis temperature. In sugarcane bagasse biochar (SBB), the trend of



Fig. 1 Available phosphorus (Olsen P) concentration of rice husk biochar (RHB)

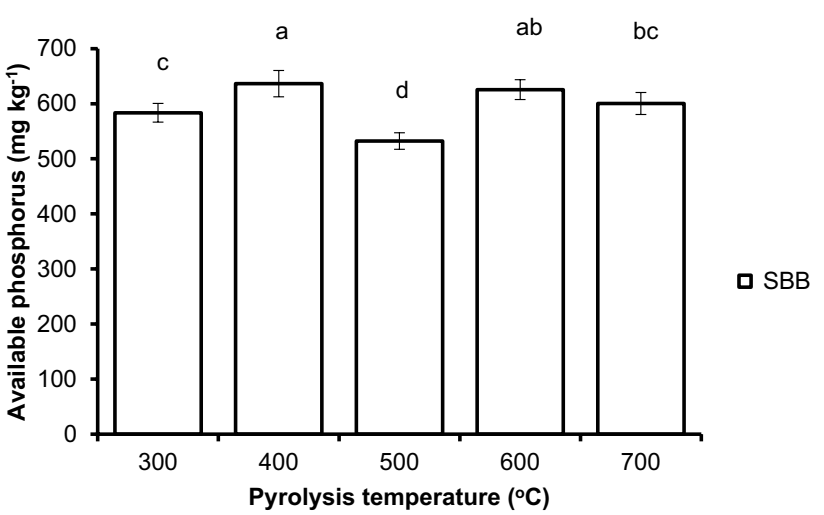

Fig. 2 Available phosphorus (Olsen P) concentration of sugarcane bagasse biochar (SBB)

the phosphorus bioavailability was not specific. Part of the reason might be because cation-phosphate complexes which exist in biochar strongly influence phosphorus reactivity and bioavailability (Hunger et al. 2008; Güngör et al. 2007). In this study, data obtained suggest that there is every possibility that $\mathrm{Ca} / \mathrm{Mg}-\mathrm{P}$ complexes dominated $\mathrm{P}$ availability. Again, the change might be because diverse forms of organic phosphorus (OP) have diverse levels of mobility. For instance, the OP bond to organic matter containing abundance of $O$-alkyl groups (e.g., phytic acid) is more labile than those containing ample refractory alkyl and aromatic carbon groups (e.g., nucleic acid and phospholipid) (Hamdan et al. 2012). Hence, the production of biochar can alter the fate of $\mathrm{P}$ by changing the form of $\mathrm{P}$ in agricultural residues.

\section{Available silicon}

Available silicon of the biomass at $P<0.05$ significantly increased with increasing pyrolysis temperature in both RHB and SBB (Table 4). In RHB, $0.01 \mathrm{M} \mathrm{CaCl}_{2}$ extracted silicon ranged from 61 to $3124 \mathrm{mg} \mathrm{kg}^{-1}$ with its maximum (3124 mg kg${ }^{-1}$ ) at $700{ }^{\circ} \mathrm{C}$. In SBB, the trend of increase continued from 350 to $500{ }^{\circ} \mathrm{C}$ (266 to $343 \mathrm{mg} \mathrm{kg}^{-1}$ ); afterwards, there was a decrease at $600{ }^{\circ} \mathrm{C}\left(275 \mathrm{mg} \mathrm{kg}^{-1}\right)$. In $0.5 \mathrm{M} \mathrm{HCl}$ and $0.1 \mathrm{M}$ citric acid extracted silicon, the range found in RHB was ( 86 to 475 and 16 to $418 \mathrm{mg} \mathrm{kg}^{-1}$ ) and SBB was (236 to 7262 and 207 to $9313 \mathrm{mg} \mathrm{kg}^{-1}$ ), respectively. The maximum of $0.5 \mathrm{M} \mathrm{HCl}$ and $0.1 \mathrm{M}$ citric acid was observed in SBB (7262 and $9313 \mathrm{mg} \mathrm{kg}^{-1}$ ), respectively, at $700{ }^{\circ} \mathrm{C}$. The increase obtained with increasing pyrolysis temperature was as a result of change in the form of silica upon heating. It is reported that the amorphous form silica changes into crystalline form when heat is applied (Todkar et al. 2016; Parry and Smithson 1964). This form change generally reduces the availability of silicon. However, our results showed reverse trend. It is probably due to the short heating 
Table 4 The available silicon of the biomass at different pyrolysis temperature under different extraction methods

\begin{tabular}{llccc}
\hline Biomass & $\begin{array}{l}\text { Temperature } \\
\left({ }^{\circ} \mathrm{C}\right)\end{array}$ & $0.1 \mathrm{M} \mathrm{CaCl}_{2}$ & $\begin{array}{l}0.5 \mathrm{M} \mathrm{HCl}_{\left(\mathrm{SiO}_{2}\right.} \\
\left.\mathrm{mg} \mathrm{kg}^{-1}\right)\end{array}$ & $0.1 \mathrm{M}$ citric acid \\
\hline Rice husk & 300 & $61 \pm 3 \mathrm{e}$ & $86 \pm 4 \mathrm{e}$ & $16 \pm 2 \mathrm{e}$ \\
& 400 & $1306 \pm 12 \mathrm{~d}$ & $117 \pm 3 \mathrm{~d}$ & $55 \pm 4 \mathrm{~d}$ \\
& 500 & $2952 \pm 51 \mathrm{c}$ & $190 \pm 10 \mathrm{c}$ & $157 \pm 6 \mathrm{c}$ \\
& 600 & $2800 \pm 12 \mathrm{~b}$ & $263 \pm 11 \mathrm{~b}$ & $214 \pm 5 \mathrm{~b}$ \\
Sugarcane bagasse & $3124 \pm 77 \mathrm{a}$ & $475 \pm 30 \mathrm{a}$ & $418 \pm 21 \mathrm{a}$ \\
& 700 & $266 \pm 10 \mathrm{~b}$ & $236 \pm 4 \mathrm{~d}$ & $207 \pm 7 \mathrm{~d}$ \\
& 350 & $333 \pm 8 \mathrm{a}$ & $259 \pm 7 \mathrm{~d}$ & $306 \pm 5 \mathrm{~d}$ \\
& 500 & $343 \pm 5 \mathrm{a}$ & $2074 \pm 20 \mathrm{c}$ & $2946 \pm 40 \mathrm{c}$ \\
& 500 & $275 \pm 3 \mathrm{~b}$ & $4686 \pm 117 \mathrm{~b}$ & $5391 \pm 145 \mathrm{~b}$ \\
& 600 & $279 \pm 4 \mathrm{~b}$ & $7262 \pm 135 \mathrm{a}$ & $9313 \pm 137 \mathrm{a}$ \\
\hline
\end{tabular}

Values followed by the same letter within RHB or SBB columns were not significantly different at $P<0.05$ according to Duncan's Multiple range test. Values represent mean \pm standard deviation of $(n=3)$ time, i.e., $10 \mathrm{~min}$. The differences observed with the different extraction methods might be a function of the chemical composition of the biomass. The amount of available silicon extracted from RHB with acidic extraction method was low when compared with SBB. Part of the reason might be because rice husk upon charring produces about 70-80\% reactive $\mathrm{SiO}_{2}$ while sugarcane is about 40-50\% (Ganesan et al. 2007). According to Patcharin et al. (2009), introduction of acid can increase the amount of silica extracted from bagasse by the removal of its alkali and alkaline metals. It is viewed that $\mathrm{CaCl}_{2}$ extraction method extracts only the soluble fraction of silica (Berthelsen et al. 2001), while that with citric acid or diluted acid (example $\mathrm{H}_{2} \mathrm{SO}_{4}$ ) extract a combination of both soluble and adsorbed silica fractions (Beckwith and Reeve 1964). This is because acidic ions compete not only with silicic acid in the sorption sites but also formed complexes with metallic ions that are known to bind silicic acid. In the present study, we could not find out the reason why available silicon in RHB was not extracted by acid solutions ( $\mathrm{HCl}$ and citric acid).

\section{Conclusion}

The data indicated that both the pyrolysis temperature and biomass significantly affect the chemical compositions of the biochar. In all, an increase in temperature leads to the generation of biochar with high nutrient content. Developing an innovative process, which can generate high temperature, would be a key priority for the local communities to improve the productivity and quality of the produced biochar. RHB at high temperature may produce nutrient-rich biochar, with high $\mathrm{pH}, \mathrm{EC}$, ash content, available silicon, phosphorus, extractable base cations for acidic soil amendment. Finally, SBB could give high available silicon with acid pre-treatment.
Acknowledgements This study was financially supported by the Ministry of Education, Culture, Sports, Science and Technology (MEXT) Japan.

Open Access This article is distributed under the terms of the Creative Commons Attribution 4.0 International License (http://creativeco mmons.org/licenses/by/4.0/), which permits unrestricted use, distribution, and reproduction in any medium, provided you give appropriate credit to the original author(s) and the source, provide a link to the Creative Commons license, and indicate if changes were made.

\section{References}

Acquaye DM, Tinsley J (1964) Soluble silica in soils. Experimental pedology. Butterworth Co., Ltd., London, pp 127-148

Ahmedna M, Johns MM, Clarke SJ, Marshall WE, Rao RM (1997) Potential of agricultural by-product-based activated carbons for use of raw sugar decolourisation. J Sci Food Agric 75:117-124. https://doi.org/10.1002/(SICI)1097-0010(19970 9)75:1<117::AID-JSFA850>3.0.CO;2-M

Almendros G, Knicker H, Gronzalez Vila FJ (2003) Rearrangement of carbon and nitrogen forms in peat after progressive thermal oxidation as determined by solid-state $13 \mathrm{C}$ - and $15 \mathrm{~N}-\mathrm{NMR}$ spectroscopy. Org Geochem 34:1559-1568. https://doi.org/10.1016/ S0146-6380(03)00152-9

Amonette J, Joseph S (2009) Characteristics of biochar: micro chemical properties. In: Lehmann J, Joseph S (eds) Biochar for environmental management: science and technology. Earthscan, London, pp 33-52

Antal Jr. MJ, Grønli M (2003) The art, science, and technology of charcoal production. Ind Eng Chem Res 42(8):1619-1640. https ://doi.org/10.1021/ie0207919

Beckwith RS, Reeve R (1964) Studies on soluble silica in soils II-the release of monosilicic acid from soils. Aust J Soil Sci 2:33-45. https://doi.org/10.1071/SR9640033

Beesley L, Moreno-Jiménez E, Gomez-Eyles JL, Harris E, Robinson B, Sizmur T (2011) A review of Biochars' potential role in the remediation, re-vegetation and restoration of contaminated soils. Environ Pollut 159:3269-3282. https://doi.org/10.1016/jenvp ol.2011.07.023 
Berthelsen S, Hurney A, Noble AD, Rudd A, Garside AL, Henderson A (2001) An assessment of current silicon status of sugar cane production soils from Tully to Mossman. Proc Aust Soc Sug Cane Techn 23:289-296

Cabrera A, Cox L, Spokas KA, Celis R, Hermosin MC, Cornejo J, Koskinen WC (2011) Comparative sorption and leaching study of the herbicides fluometuron and 4-Chloro-2- methylphenoxyacetic acid (MCPA) in a soil amended with biochars and other sorbents. J Agric Food Chem 59:12550-12560. https://doi. org/10.1021/jf202713q

Camps-Arbestain M, Amonette JE, Singh B, Wang T, Schmidt HP (2015) A biochar classification system and associated test methods. In: Lehmann J, Joseph S (eds) Biochar for environmental management: science, technology and implementation, 2nd edn. Rutledge, London, pp 165-193

Chan K, Xu Z (2009) Biochar: Nutrient Properties and Their Enhancement. In: Lehmann J, Joseph S (eds) Biochar for Environmental Management: Science and Technology. Earthscan, London, pp 67-84

Chen Y, Yang H, Wang X, Zhang S, Chen H (2012) Biomass-based pyrolytic polygeneration system on cotton stalk pyrolysis: influence of temperature. Bioresour Technol 107:411-418. https:// doi.org/10.1016/j.biortech.2011.10.074

Chun Y, Sheng Chiou CT, Xing B (2004) Compositions and sorptive properties of crop residue-derived chars. Environ Sci Technol 38(17):4649-4655. https://doi.org/10.1021/es035034w

Ding Y, Liu YX, Wu WX, Shi DZ, Yang M (2010) Evaluation of biochar effects on nitrogen retention and leaching in multi-layered soil columns. Water Air Soil Pollut 213:47-55. https://doi. org/10.1007/s11270-010-0366-4

Downie A, Crosky A, Munroe P (2009) Physical Properties of Biochar. In: Lehmann J, Joseph S (eds) Biochar for environmental management: science and technology. Earthscan, London, pp $13-32$

FOASTAT (2014) Sugar cane, production quantity (tons) — for all countries. http://www.factfish.com/statistic/sugar\%20cane\%2C\%20pro duction\%20quantity Accessed 20 Dec 2017

Gai X, Wang H, Liu J, Zhai L, Liu S (2014) Effects of feedstock and pyrolysis temperature on biochar adsorption of ammonium and nitrate. PLoS One 9(12):e113888. https://doi.org/10.1371/journ al.pone. 011388

Ganesan K, Rajagopal K, Thangavel K (2007) Evaluation of Bagasse ash a supplementary cementious material. Cement Concrete Composit 29(6):515-524. https://doi.org/10.1016/j.cemconcomp .2007.03.001

Gaskin JW, Steiner C, Harris K, Das KC, Bibens B (2008) Effect of low-temperature pyrolysis conditions on biochar for agricultural use. Trans ASABE 51:2061-2069

Giddel MR, Jivan AP (2007) Waste to wealth, potential of rice husk in India a literature review. In: Proc of the inter confer on cleaner technol and environ Mgt PEC, Pondicherry, India. 586-590

Güngör K, Jürgensen A, Karthikeyan KG (2007) Determination of phosphorus speciation in dairy manure using XRD and XANES spectroscopy. J Environ Qual 36:1856-1863. https://doi. org/10.2134/jeq2006.0563

Hamdan R, El-Rifai HM, Cheesman AW, Turner BL, Reddy KR, Cooper WT (2012) Linking phosphorus sequestration to carbon humification in wetland soils by P-31 and C- 13 NMR spectroscopy. Environ Sci Technol 46(9):4775-4782. https://doi. org/10.1021/es204072k

Cao XD, Harris W (2010) Properties of dairy-manure- derived biochar pertinent to its potential use in remediation. Bioresour Technol 101:5222-5228. https://doi.org/10.1016/j.biortech.2010.02.052

Haysom MBC, Chapman LS (1975) Some aspect of calcium silicate trials at Mackay. Proc Queensl Soc Sugarcane Technol 42:117-122
Hongguang C, Davey LJ, Paul H, Mohd SB, Cheng LT (2017) Influence of biochar produced from different pyrolysis temperature on nutrient retention and leaching. Arch Agron Soil Sci. https://doi. org/10.1080/03650340.2017.1384545

Hunger S, Sims JT, Sparks DL (2008) Evidence for struvite in poultry litter: effect of storage and drying. J Environ Qual 37:1617-1625. https://doi.org/10.2134/jeq2007.0331

Johansen JM, Jakobsen JG, Frandsen F, Glarborg P (2011) Release of $\mathrm{K}, \mathrm{Cl}$, and $\mathrm{S}$ during pyrolysis and combustion of high-chlorine biomass. Energy Fuels 25(11):4961-4971. https://doi. org/10.1021/ef201098n

Kammann CI, Linsel S, Gößling JW, Koyro HW (2011) Influence of biochar on drought tolerance of Chenopodium quinoa willd and on soil-plant relations. Plant Soil 345:195-210. https://doi. org/10.1007/s11104-011-0771-5

Knicker H, Hatcher PG (1997) Survival of protein in an organic-rich sediment: possible protection by encapsulation in organic matter. Naturwissenschaften 84:213-234

Knoepp JD, DeBano LF, Neary DG (2005) Soil chemistry. In: Neary Daniel G., Ryan Kevin C., DeBano Leonard F (eds) Wild land fire in ecosystems: effects of fire on soils and water. Gen. Tech. Rep. RMRS- GTR-42- vol. 4. U.S. Department of Agriculture, Forest Service, Rocky Mountain Research Station, Ogden, pp 53-71

Koutcheiko S, Monreal CM, Kodama H, McCracken T, Kotlyar L (2006) Preparation and characterization of activated carbon derived from the thermo-chemical conversion of chicken manure. Bioresour Technol 98:2459-2464. https://doi.org/10.1016/j.biort ech.2006.09.038

Kudeyarova AY (2007) Application of basic chemical concepts to understanding the formation and transformation mechanisms of humic substances: a revue of publications and own experimental data. Euras Soil Sci 40:934-948. https://doi.org/10.1134/s1064 229307090037

Kumar S, Sangwan P, Dhankhar R, Mor V, Bidra S (2013) Utilization of rice husk and their ash: a review. Res J Chem Env Sci 1(5):126-129

Lehmann J, Joseph S (2009) Biochar for environmental management: science and technology. Earthscan, London, pp 1-12

Lehmann J, Rillig MC, Thies J, Masiello CA, Hockaday WC, Crowley D (2011) Biochar effects on soil biota-a review. Soil Bio Biochem 43:1812-1836. https://doi.org/10.1016/jsoilbio.2011.04.022

Lei O, Zhang R (2013) Effects of biochars derived from different feedstocks and pyrolysis temperatures on soil physical and hydraulic properties. J Soil Sediment 13:1561-1572. https://doi. org/10.1007/s11368-013-0738-7

Mukome FND, Zhang X, Silva LCR, Six J, Parikh SJ (2013) Use of chemical and physical characteristics to investigate trends in biochar feedstocks. J Agri Food Chem. https://doi.org/10.1021/jf304 9142

Muthadhi A, Anitha R, Kothandaraman S (2007) Rice husk ash properties and its uses: a review. J Inst Eng 88(5):50-56

National Agricultural Extension and Research Liaison Services and Projects Coordinating Units (2004) Field situation study. NAERLS/PCU. October 13, 2003-January 9, 2004

Okuno T, Sonoyama N, Hayashi JI, Li CZ, Sathe C, Chiba T (2005) Primary release of alkali and alkaline earth metallic species during the pyrolysis of pulverized biomass. Energy Fuel 19:21642171. https://doi.org/10.1007/s001140050384

Olsen SR, Sommers LE (1982) Determination of available phosphorus. In: Page AL, Miller RH, Keeney DR (eds) Method of soil analysis, vol 2. American Society of Agronomy, Madison, p 403

Parry DW, Smithson F (1964) Types of opaline silica deposition in the leaves of British grasses. Ann Bot Lond 28:169-185. https://doi. org/10.1093/oxfordjournal.aob.a083891 
Patcharin W, Wisaroot P, Akhapon M (2009) Characterization for post treatment effect of bagasse ash for silica extraction. World Acad Sci Eng Technol 3:339-349

Savant NK, Korndorfer GH, Datnoff LE, Snyder GH (1999) Silicon nutrition and sugarcane production. J Plant Nutr 22(12):18531903. https://doi.org/10.1080/01904169909365761

Singh B, Singh BP, Cowie AL (2010) Characterization and evaluation of biochars for their applications a soil amendment. Aust J Soil Res 48:516-525. https://doi.org/10.1071/SR10058

Thangalazhy-Gopakumar S, Adhikari S, Ravindran H, Gupta RB, Fasina O, Tu M, Fernando SD (2010) Physiochemical properties of bio-oil produced at various temperatures from pine wood using an auger reactor. Bioresour Technol 101(21):8389-8395. https:// doi.org/10.1016/j.biortech.2010.05.040

Todkar BS, Deshmukh SM, Deorukhka OA (2016) Extraction of silica from rice husk. Int J Eng Res Dev 12:69-74

Tsai WT, Liu SC, Chen HR, Chang YM, Tsai YL (2012) Textural and chemical properties of swine-manure derived biochar pertinent to its potential use as a soil amendment. Chemosphere 89(2):198203. https://doi.org/10.1016/j.chemosphere.2012.05.085

UNEP (2009) Converting waste agricultural biomass into resource: compendium of technologies. United Nations Environmental Programme 2009, Division of Technology, Industry and Economics International Environmental Technology Centre Osaka/Shiga, Japan, pp 441

United Nations Department of Economic and Social Affairs: Population Division (2017). http://esa.un.org/unpd/wpp. Accessed 17 Sep 2017
Van Lith SC, Jensen PA, Frandsen F, Glarborg P (2008) Release to the gas phase of inorganic elements during wood combustion part 2: influence of fuel composition. Energy Fuel 22(3):1598-1609. https://doi.org/10.1021/ef060613i

Van Zwieten L, Singh B, Joseph S, Kimber S, Cowie A, Chan KY (2009) Biochar and emissions of non-CO2 greenhouse gases from soil. In: Lehmann J, Joseph S (eds) Biochar for environmental management-science and technology. Earthscan, London, pp 227-249

Walsh ME, Perlack RL, Turhollow A, de la Torre Ugarte D, Becker DA, Graham RL, Slinsky SE, Ray DE (2000) Biomass feedstock availability in the United States: 1990 State level analysis. Available via bioenergy.ornl.gov. Oak Ridge National Laboratory, Oak Ridge

Yuan J, Xu R, Zhang H (2011) The forms of alkalis in the biochar produced from crop residues at different temperatures. Bioresour Technol 102:3488-3497. https://doi.org/10.1016/j.biort ech.2010.11.018

Publisher's Note Springer Nature remains neutral with regard to jurisdictional claims in published maps and institutional affiliations. 